Marquette University

e-Publications@Marquette

History Faculty Research and Publications

History, Department of

4-1-2013

Mortuary Workers, the Church, and the Funeral Trade in Late Antiquity

Sarah E. Bond

Marquette University, sarah.bond@marquette.edu

Published version. Journal of Late Antiquity, Vol. 6, No. 1 (Spring 2013): 135-151. DOI. (c) 2013 Johns Hopkins University Press. Used with permission. 


\title{
Mortuary Workers, the Church, and the Funeral Trade in Late Antiquity
}

\begin{abstract}
Within the city of Constantinople, Constantine organized numerous funeral workers into associations overseen by a bishop, as part of a scheme meant to provide burials for all who needed them within the city. The funeral workers were given special exemptions and clerical status in return for their services. Constantine's model was imitated in other cities within the eastern Mediterranean and, as a result, established new urban patronage networks. The newly elevated funeral professionals were liminal men, between the commercial and clerical worlds and dependent on bishops for their employment and status. Some bishops exploited this dependency by using funeral workers as personal militias. Inscriptions and legal evidence also point to the increasing influence of the church in the funeral trade. Although Constantine envisioned a city that exemplified the Christian belief in provision of burial to all, his scheme had numerous unintended consequences. Investigation of these funeral associations reveals the role of the bishop as a patron, funeral director, and businessman during the Late Roman Empire and better defines the involvement of the church in the funeral trade in Late Antiquity.
\end{abstract}

The subsidization of funeral workers by the state is indicated in two sixthcentury novels of Justinian that reference Constantine's establishment of associations of decani (funeral directors) and lecticarii (corpse-bearers) overseen by the bishop in Constantinople during the early fourth century. ${ }^{2}$ Together, these rulings outlined the emperor's novel system, which intended to ensure the burial of all residents in Constantinople, except heretics. This burial scheme marked a notable policy shift in that the state now provided liturgical exemptions and subsidies to funeral workers who performed burials for the

\footnotetext{
${ }^{1}$ Many thanks to Richard Talbert, James Rives, Brett Whalen, Werner Riess, Fred Naiden, and Michael Kulikowski for their helpful comments.

${ }^{2}$ Nov.Just. 43 (536), 59 (537). See Peter Brown, Poverty and Leadership in the Later Roman Empire (Hanover, 2002), 76-77; Éric Rebillard, The Care of the Dead in Late Antiquity, E. Trapnell Rawlings, J. Routier-Pucci, trs. (Ithaca, 2009), 121-122; Idem, "Les formes de l'assistance funéraire dans l'empire romain et leur évolution dans l'antiquité tardive," Antiquité tardive 7 (1999), 269-282.
} 
populace. ${ }^{3}$ Justinian states that Constantine's scheme established 950 trade workshops in Constantinople that would provide funeral workers assembled into associations for the church's use; in return, these workshops were given exemption from certain munera and assigned quasi-clerical status. ${ }^{4}$ Modifications were subsequently made to Constantine's original plan; pivotal additions were Anastasius' increase in the number of exempted workshops from 950 to 1,100 and his allocation of state land to church officials in order to defray burial costs and fund the program. The novels of Justinian reveal that by the sixth century the system needed to be modified yet again and further protected from the corruption that (at least according to the legal codes) plagued the burial system in Constantinople. The significance of the scheme lies in the creation of a united corporation of funeral workers in Constantinople and the investment of bishops as patrons over these associations. The transference of the powers of patronage from imperial administrators and into the hands of bishops was a pivotal trend in Late Antiquity that conveyed popular relationships from state figures to religious leaders.

The importance of Constantine's burial scheme, which provided tax exemptions and clerical status in order to attract and maintain funeral workers, namely the lecticarii and the decani, was its codification of a funerary system that was overseen by the local church and supported by the state. Constantine's system provided a paradigm for the provinces and increased the number of funeral workers who enjoyed state benefits while also acquiring status as lower-level clerics. Whereas some churches employed associations of funeral workers along the model of Constantinople, as did the copiatae in Asia Minor, others expanded their minor orders to include groups to care for the sick and dying, such as the parabolani in Alexandria. ${ }^{5}$ Because these lower orders of clerics were not identical within sixth-century churches, where this investigation ends, it is necessary to deal with the evidence for associations of funeral workers within their own sociocultural milieux and respective cities. ${ }^{6}$ Although Constantine's scheme was not monolithically institutionalized

${ }^{3}$ See Gilbert Dagron, “Ainsi rien n'échappera à la réglementation: État, église, corporations, confréries: àpropos des inhumations à Constantinople ( $\mathrm{IV}^{\mathrm{e}}-\mathrm{X}^{\mathrm{e}}$ siècle)," in V. Kravari, J. Lefort, C. Morrisson, eds., Hommes et richesses dans l'Empire byzantin, II: VIIIe-XVe siècle (Paris, 1991), $155-182$.

${ }^{4}$ CJ 1.3.22 indicates that they received the same exemptions from taxes as clerics and were generally treated together with clerici and other ecclesiastical workers.

${ }^{5}$ Copiatae: Note the numerous epitaphs for the copiatae in Asia Minor: JHS 19 (1899), 98, no. 84; MAMA 3.294; MAMA 3.260. Textual evidence for their clerical status: Pseudo-Ignatius, Epist. 9.12, written in the second half of the fourth century, cites them as a clerical order, as does Epiphanius, Haer. 3.522, and CTh 16.2.15.1. For parabolani (or parabalani), CTh 16.2.42.

${ }^{6}$ On the lack of consistency in the minor orders: Allen E. Jones, Social Mobility in Late Antique Gaul: Strategies and Opportunities for the Non-elite (New York, 2009), 233-246; note also 
throughout the Roman Empire, there are strong trends among these clerical funeral workers' associations in terms of their patronage, mobilization, and role within the expanding commercial interests of many early Christian churches in the funeral trade.

There were numerous associations of funeral workers connected to Christian churches within the Roman Empire prior to Constantine. However, the emperor invested the church in a pivotal role within the organization of the funeral trade at Constantinople, as an arch-funeral director of burials and overseer of large associations of workers. ${ }^{7}$ As such, he made a more networked burial community within the city that appears to have inspired the organization of burial schemes in places such as Antioch and Ephesus. The genuine concern with which Constantine approached the poor, and his use of bishops, men who were explicitly not of the elite class, has been a fruitful and interesting area of study. ${ }^{8}$ Yet not enough is understood about the impact of Constantine's scheme in terms of patronage or the increasing significance of burial placement and the selling of burial spaces in Late Antiquity, especially in regard to the phenomenon called the "cult of the saints." Literary texts such as the Gospels, the acts of the martyrs, and saints' lives helped to reinforce the initial burial duty and funerary network, and, later, bishops hired continually larger staffs in order to implement this ideal within increasingly larger Christian communities.

Whereas funeral workers in the Roman Republic and early empire appear marginalized and stigmatized by their association with corpses and profiting from death, Christian funeral workers were viewed as providing a pivotal and pious service. ${ }^{9}$ Mortuary workers never achieved great prominence within early churches, but they did achieve an improved social position and, in some cases, a clerical position. Despite new titles and exemptions, the

the examples provided by female deacons and presbyters: Kevin Madigan, Carolyn Osiek, eds., Ordained Women in the Early Church: A Documentary History (Baltimore/London, 2005).

${ }^{7}$ Note the fossores listed among the clergy at Cirta in 303: Opt. App. $1=$ Gest.ap.Zenophil . 3. Fossores also were cited as the lowest-ranking of the clerical orders in the pseudo-Hieronymian De septem ordinibus ecclesiae (PL 30.150): "Primus igitur in clericis fossariorum ordo est, qui in similitudintm Tobiae sancti, sepelire mortuos admoneatur." But for a rebuttal of fossores and funeral workers as clerics in Late Antiquity, see Rebillard, Care of the Dead, 119-121.

${ }^{8}$ See Chiara Corbo, Paupertas: La legislazione tardoantica (IV-V sec. d.C.) (Naples, 2006). See also Peter Brown, Through the Eye of a Needle: Wealth, the Fall of Rome, and the Making of Christianity in the West 350-550 AD (Princeton, 2012), 43-45.

${ }^{9} A E$ (1971), 88.2.3-6. For the disrepute of republican-era funeral workers in Italy, see John Bodel, "Dealing with the Dead: Undertakers, Executioners, and Potter's Fields in Ancient Rome," in V. Hope, E. Marshall, eds., Death and Disease in the Ancient City (London/New York, 2000), 128-151; François Hinard, Jean Christian Dumont, eds., Libitina: Pompes funèbres et supplices en Campanie à l'époque d'Auguste: Édition, traduction et commentaire de la Lex Libitinae Puteolana (Paris, 2003). 
job entailed many of the same duties it had during the pre-Christian period. The lecticarii and decani were themselves liminal in a sense: betwixt and between the commercial and clerical worlds, dependent on bishops for their employment and status.

Constantine's scheme was an imperfect system that, as indicated by the novels and late antique law codes, was perhaps manipulated by its participants. Both bishops and funeral workers appear implicated in this development. Besides the elevation in status of these workers, the effect of the creation of ordines of funeral workers was twofold: first, it was related to a change in the bishop-patron's relationship with these ordines, which created the potential to use their personnel as gangs under the leadership of the bishop; second, it was related to the systemic corruption in the trade made possible by statusseeking individuals who wanted to be buried near saints. As will be shown below, the cyclical status change, which swung back to low or poor status in some areas, was likely the result of one or more systemic issues. The veneer of the pious Christian funeral worker, once rehabilitated in the early formation of Christianity, had again become tarnished by the mid-sixth century. This was perhaps due to the rapid administrative and social expansion of the church caused by the assimilation of large groups of workers directed by bishops who, in some areas, abused their funeral clientes. The church became increasingly involved in the funeral trade and in designating ad sanctos burials and, thus, became separated from the more charitable view of burials that had prevailed within the second, third, and early fourth centuries.

\section{Bishop and Patron: Funeral Workers as Personal Gangs}

There are numerous examples from Late Antiquity of funeral associations used as personal militias by their bishop-patrons. Perhaps the earliest instance is Damasus, who hired factions of arenarii (arena workers), quadrigarii (charioteers), and fossores (gravediggers) in 366 CE to storm the Basilica Iulii and the Basilica Liberii in a coup to overthrow Ursinus, the current bishop of Rome..$^{10}$ The subsequent raid resulted in the death of 137 of Ursinus' supporters, the overthrow of the bishop, and the establishment of Damasus as the new bishop of Rome. Ammianus' account of Damasus' coup perhaps offers broader insight into the competitive political tensions and elevation of the bishop in late antique cities, because, in Ammianus' estimation, the new bishop's use of force had been undertaken in the hopes of obtaining the wealth

${ }^{10}$ Coll Avell. 1.7 = CSEL 35.3: “Tunc Damasus cum perfidis invitat arenarios quadrigarios et fossores omnemque clerum cum securibus gladiis et fustibus et obsedit basilicam hora diei secunda septimo Kalendarum Novembrium die Gratiano et Dagalaifo conss. et grave proelium concitavit." 
and status that came with the bishopric of Rome. ${ }^{11}$ Ammianus claims that upon attaining the office, popes could expect to be "enriched from the offerings of matrons, ride seated in carriages, wearing clothing chosen with care, and serve banquets so lavish that their entertainments outdo the tables of kings." ${ }^{12}$ As a means of attaining such an office, ambitious clergymen in Late Antiquity appear to have sometimes relied upon the lower-level funeral professionals that they had come to patronize. The creation of large civic associations put under the direction of the bishop as patronus often established the bishop as the benefactor to many lower-level workers and endowed the bishop with a strong client base. At times, late antique bishops used these civic associations-particularly associations of funeral workers-in violent attempts to assert their power.

Since Paul himself, Christian bishops had billed themselves as the champions of the poor, and in Late Antiquity these figures were often called upon for popular support. As a result of this benefaction and Constantine's shift of patronage responsibilities from administrators to ecclesiastical leaders, by the end of the fourth century bishops had become powerful patrons to civic associations and to the urban capite censi and could command large crowds. ${ }^{13}$ The bishop also quelled social unrest by exercising power over the fringe groups of the poor. ${ }^{14}$ Within many late antique communities the bishop became the arch-patron, a figure who subsumed the duties of providing euergetism and beneficia once considered the officium of duovirs and other leading men and women within a city. As the head of the episcopate of Constantinople, the archbishop had by the mid-fourth century become patron to an estimated 2,000 clerici-including the 950 decani and lecticarii put under his direction by Constantine. ${ }^{15}$ Bishops in Constantinople, Alexandria, and throughout the Roman Empire played a dual role as religious leader and patron to thousands of clerics and laity, who depended upon them economically and socially.

Textual and legal evidence indicates that bishops often established strong patron-client relationships with gravediggers, the personnel who worked with

${ }^{11}$ Amm. Marc. Res gest. 27.3.12-13.

${ }^{12}$ J.C. Rolfe, tr., Amm. Marc. Res gest. 27.3.14: "Ut ditentur oblationibus matronarum, procedantque vehiculis insidentes circumspecte vestiti, epulas curantes profusas adeo ut eorum convivia regales superent mensas."

${ }^{13}$ Note Ambrose's comment (Epist. 40.6) that bishops were "controllers of crowds, the keen upholders of peace, unless, of course, they are moved by insults to God and to His Church"; see Peter Brown, Power and Persuasion in Late Antiquity: Towards a Christian Empire (Madison, 1992), 71-117.

${ }^{14}$ Brown, Power and Persuasion, 77-78.

${ }^{15}$ Peter Norton, Episcopal Elections 250-600: Hierarchy and Popular Will in Late Antiquity (Oxford/New York, 2007), 69. 
the sick, and other funeral workers such as mourners and musicians-much in the way that the dissignator appeared as a central patron among the collegia within the funeral trade at Rome. The poor were particularly indebted to the church for employment, "from prestigious positions (such as a steward) involved with the financial management of the church down to the lowly doorkeepers and gravediggers." ${ }^{16}$ The church was indeed a social vehicle, but for those formerly disreputable, as funeral workers had been in the Republic and early Roman Empire, it remains to be considered whether there was a stronger dependency on a bishop in order to maintain this elevated status. ${ }^{17}$ Could it be that bishops favored funeral workers for their dependency on them for status as well as for their physical abilities?

\section{The Parabolani at Alexandria}

For thousands of years Egypt supported a highly organized funeral trade that was overseen by a head priest, employed hundreds of skilled artisans, and maintained its necropolis trade into Late Antiquity. ${ }^{18}$ The workshops and funeral trade within Egyptian necropoleis is notable in that in Roman Egypt, as in Italy, funeral workers were often viewed as persons kept outside the city gates. Yet out of the Alexandrian church's necessity for specialized persons to care for the sick and to dispose of bodies from hospitals, a group named the parabolani or $\pi \alpha \rho \alpha ́ \beta \beta \lambda$ or (those who undergo danger) was instituted and placed under the direction of the bishop, probably in the late fourth century. ${ }^{19}$ The parabolani would become traditionally cited for their brutality and use by the bishop Cyril as a gang within the city of Alexandria; however, like the lecticarii and decani in Constantinople, they represent a key ecclesiastical association newly interwoven into the civic fabric. ${ }^{20}$ Moreover, like the copiatae, these parabolani are cited within the Theodosian Code as clerics. ${ }^{21}$

${ }^{16}$ Norton, Episcopal Elections, 69.

17 Their disrepute is recognized in a late republican inscription, $A E$ (1971), 88. See Bodel, "Dealing with the Dead," 128-151. For the funeral trade in Italy during the Republic see Idem, "Graveyards and Groves: A Study of the Lex Lucerina," AJAH 11 (1994), 1-133; Idem, "The Organization of the Funerary Trade at Puteoli and Cumae," in S. Panciera, ed., Libitina e dintorni: Libitina e iluci sepolcrali, le leges libitinariae campane, jura sepulc(rorum: vecchie e nuove iscrizioni: atti dell'XI Rencontre franco-italienne sur l'épigraphie (Rome, 2004), 147-68; note also Hinard, Dumont, Libitina.

${ }^{18}$ See Tomasz Derda, "Necropolis Workers in Graeco-Roman Egypt in the Light of the Greek Papyri,” JJP 21 (1991), 13-36.

${ }^{19}$ François Martroye, "Les parabalani,” BSAF (1923), 275-285.

${ }^{20}$ They are often used as an illustration of the increase in violence in Late Antiquity; see Brown, Power and Persuasion, 103-104, 113-115.

${ }^{21}$ CTh 16.2.42 (416). 
The associative structure of these funeral workers was not all that different

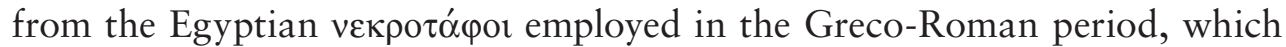
guarded and tended to the necropoleis there. The key difference was the shift in status and patronage. The Egyptian priests who oversaw necropoleis and a large number of funeral workshops are similar to the bishops who directed the parabolani. In terms of reputation, however, the parabolani became notorious for gang violence under the direction of their bishop-patrons, while still maintaining an important civic function. ${ }^{22}$ Laws from the beginning of the fifth century-when the parabolani began to be associated with numerous civil disturbances-ruled that the parabolani could only be drawn from the lower classes. This restriction perhaps shows that although they were technically clerics, esteem for gravediggers and bier-carriers in early Christianity was in some areas regressing, reverting back to a vocation reserved for the poor, as it had been in Italy in the late Republic. ${ }^{23}$

In $416 \mathrm{CE}$, the parabolani of Alexandria were notoriously used in the feud between Cyril, the bishop of Alexandria, and Orestes, an imperial administrator, as a personal gang for the bishop. In reaction to Cyril's use of these workers in acts of violence against his opponents, the Alexandrians sent a deputation to Theodosius II, who in turn sent a ruling to the praetorian prefect Monaxius instructing that the parabolani be put under the state's power, and not the bishop's; furthermore, the emperor capped the association at 500 men and stipulated that they be chosen from the poorer classes. ${ }^{24}$ The parabolani were not successfully placed under secular authority, however, and within two years their numbers were increased to 600 . They were placed back under the supervision of a patriarch of the church and reestablished patronage bonds with officials within the church at Alexandria. ${ }^{25}$ Cyril's successor, Dioscorus, would become well known for using the parabolani at the Council of Ephesus in $449 \mathrm{CE}$ as a type of bodyguard that would violently force bishops to sign a resolution against Flavian and Eusebius in accordance with Dioscorus' wishes. Later, the violent acts at the council would give it the ignominious name of Latrocinium ("The Robber Council"), and Flavian would die from the injuries sustained from his beatings. As a result, the parabolani gained a reputation for thuggish behavior and violence that appears to have conjured fear among citizens rather than clerical deference.

\footnotetext{
${ }^{22}$ It is unclear whether the murder of the philosopher Hypatia, which pagans attributed to Cyril and his gangs, was carried out by the parabolani (Socrates, HE 7.15).

${ }^{23}$ CTh 16.2.42-43, 12.12.15; see Alexandre Philipsborn, "La compagnie d'ambulanciers 'parabalani' d'Alexandrie," Byzantion 20 (1950), 185-190; Wilhelm Schubart, "Parabalani," JES 40 (1954), 97-101.

${ }^{24}$ CTh 16.2.42.1.

${ }^{25}$ CTh 16.2.43.
} 
The notorious actions of the parabolani at the Council of Ephesus in 449 appear to have overshadowed their civic work; however, a list of offices from the sixth or seventh century does record their continued use, as well as the employment of lecticarii to carry biers, within the city of Alexandria. ${ }^{26}$ Although noted for their violent escapades, the parabolani were initially intended as laborers who would support the health care and burial endeavors of the Alexandrian church. But with the growth of the bishop-patron, the might of these men (no doubt physically rather large, and terrifying to meet face to face on the street or within an ecumenical council) undermined the rehabilitation that the gravedigger had undergone in the early days of Christianity. Elsewhere in the Greek east, it was the funeral workers termed lecticarii who became infamous for their violent acts. The Life of Alexander Akoimetos mentions that a subdeacon appealed to the bishop of Antioch to drive out Alexander-viewed as a troublesome monk who was subverting the power of the local clergy in the late fourth or early fifth century. The subdeacon then used the lecticarii, under the direction of the patriarch, to overcome the monk and his supporters among the urban poor. ${ }^{27}$ Much as the parabolani in Alexandria formed a personal militia, the lecticarii were apparently used to keep order in Antioch and to promote their bishop-patrons in synods. It appears that from the fourth century onward, in many cities, funeral workers performed more than just burial duties on behalf of the church. ${ }^{28}$

This abuse of the associations of mortuary workers was well known and a source of concern to emperors such as Justinian. In his novels, Justinian warned that a funerary collegium could be taken away if it extended undue patronage in the form of military protection: "For as each one looks out for his own interests, it is necessary for us to look out for the interest and advantage of this great imperial city." ${ }^{29}$ The mortuary ordines, many of which had initially been formed in order to provide free or greatly reduced burials to Christians, were again returned to a highly vulnerable state. Although disreputable mortuary workers had once been vulnerable to legal persecution and were without status, they now stood in the precarious position of being dependent on the church to maintain their status and benefits. As a result, these associations began to identify with the ideology of the bishop rather than the ideology of charity within the church, and with this shift the status of many mortuary associations again began to fall into disrepute. Their

\footnotetext{
${ }^{26}$ P.Iand. 8.154.

${ }^{27}$ Daniel Caner, tr., Wandering, Begging Monks: Spiritual Authority and the Promotion of Monasticism in Late Antiquity (Berkeley/ Los Angeles, 2002), 273, sec. 40-1 (689-9).

${ }_{28}^{2}$ Brown, Power and Persuasion, 102-103.

${ }^{29}$ Nov.Just. 43.3: "Sicut enim unusquisque sui providet, ita et nos necesse est quod commodum est et utile magnae huic regiae defendere civitati."
} 
association with violence is thus one reason for their demotion in status, but another possible reason for their decline in respectability involves the growth of the funeral trade in Late Antiquity and the increased competition to attain burial spaces next to saints.

\title{
Funeral Workers, the Church, and the Selling of Tombs
}

\author{
Serep[e]ntiu \\ s emit $\operatorname{loc}(u)$ \\ $m$ a Quinto \\ fossore ad \\ san(c)tum Cor/nelium.
}

Serpentius bought from Quintus the fossor a grave near St. Cornelius. ${ }^{30}$

For all the differentiation in clergy and personnel throughout the Mediterranean, there were consistencies in the funeral markets at play within the Roman Empire: namely, the growth of cemeteries and the increasing hunger for ad sanctos burials. As cemeteries became crowded and the cities of the dead progressively more status-driven, the desire for a position next to a saint's body or relic helped to fuel a strong funeral trade that by the fifth century was controlled predominantly by the church in many cities. This was achieved in part through the bishops' control over large bands of funeral workers and the ownership of numerous burial areas by churches. This increasingly commercial, as opposed to charitable, provision of burials ultimately undermined the earlier, more positive construction of the Christian gravedigger, one that had been based on the ideal models of Joseph of Arimathea and Christ.

The increased organization of the funeral trade in Late Antiquity is aptly illustrated by analogy with the rôle of the bishop within the cult of the saints. Referring to Ambrose's introduction of the cult of the martyrs in Milan, Peter Brown notes that the bishop was "like an electrician who rewires an antiquated wiring system: more power could pass through stronger, better insulated wires toward the bishop as the leader of the community." ${ }^{31}$ We should perhaps think of the decani who organized funerals in Constantinople, the fossores who protected and decorated the catacombs in Rome, and the copiatae in Asia Minor as assistants to their arch-electrician, the bishop. ${ }^{32}$ Focus on this "rewiring" has been biased towards the establishers of the network-the

\footnotetext{
${ }^{30}$ ICUR n.s. 4.9441 = ILCV 2131.

${ }^{31}$ Peter Brown, Cult of the Saints: Its Rise and Function in Latin Christianity (Chicago, 1982), 37.

${ }^{32}$ For fossores, Elena Conde Guerri, Los “fossores” de Roma paleocristiana: estudio iconográfico, epigráfico y social (Vatican City, 1979); Jean Guyon, "La Vente des tombes à travers l'épigraphie de la Rome chrétienne (III ${ }^{\mathrm{e}}-\mathrm{VII}^{\mathrm{e}}$ siècles): le role de fossores, mansionarii, praepositi et
} 
bishops-rather than its executors and protectors, yet these funeral workers were integral to the function of the funeral trade as a whole. Although they profited from the growth of the cult of saints, the increased commodification of burial spaces involved funeral workers in a profitable business that was far removed from the pious work associated with the early Christian buriers who sought to provide dignified burials to the poor and to the martyrs.

Even before the church dominated the real estate market for burials, it supplied funeral equipment such as shrouds and biers. As seen in Rome and in Alexandria, members of the clergy increasingly began to realize the commercial opportunities presented by death and burial. George of Alexandria, the fourth-century bishop of Alexandria appointed by Constantius, was accused of funeral extortion by limiting the number of biers for the dead and dying and by ordering that only his officials were allowed to transport bodies. ${ }^{33}$ Epiphanius claimed that George did this so as to turn a profit on the corpses being buried. In 361, mob violence broke out as a result of the bishop's extortion and general oppression. He was assassinated, and his mutilated body was loaded on a camel and taken to the shore, where it was burned and the ashes then thrown into the sea. ${ }^{34}$ As this example from Alexandria illustrates, the Christian church in many areas had begun to become an integral part of the funeral trade, and to manipulate the system.

There was great variation in burial practices, options, and styles in early Christian Rome, and private entrepreneurs-such as the ones who previously inhabited the grove of Libitina-provided a wide variety of options to consumers. Increasing involvement in the burial market eventually allowed the church to dominate the management of the dead, particularly through the provision of goods (such as burial spaces and shrouds) and services (such as grave digging and bier carrying). ${ }^{35}$ Furthermore, as the populace increasingly relied on it for the provision of these goods and services, the church became entrenched in the civic order: "The treatment of the dead saw originally civic rituals and institutions gradually coalesce with those of the Church." ${ }^{36}$ Textual evidence indicates that the church still involved itself in the burial of the poor, but it had a significant commercial stake in many burials within imperial cities as well. Saints and relics, possessions often controlled by the church, were

prêtres," Melanges d' archéologie et d'histoire: Antiquité 86.1 (1974), 549-596; Henri Leclercq, "Fossoyeurs," DACL 5.2 (1923), 2065-2092.

${ }^{33}$ Epiph. Pan., "Against Anomoeans," 3.76.1.6-7: Frank Williams, tr., The Panarion of Epiphanius of Salamis: Books II and III (sects. 47-80, De Fide) (Leiden, 1994), 498.

${ }^{34}$ Amm.Marc. Res.gest. 22.11.10.

${ }^{35}$ Marios Costambeys, "Burial Topography and the Power of the Church in Fifth- and SixthCentury Rome,” PBSR 69 (2001), 169-189, esp. 170.

${ }^{36}$ Costambeys, "Burial Topography," 182. 
increasingly used as key selling points to lure pilgrims and to attract buyers who desired burial intra limina sanctorum. As Prudentius noted, the city of Rome was indeed rich in saints' tombs: "Scarce is known ... how rich is Rome in tombs of saints, how fruitful is her kindly soil in consecrated sepulchers." ${ }^{37}$ An epitaph from $381 \mathrm{CE}$ characterizes the competition to inhabit these rich lands and the vacant spots available within them: "(a sepulcher) within the boundaries of the saints, a thing which many desire and few obtain." ${ }^{38}$ By the fourth century, burial position could denote status, and funeral workers were essential in maintaining this hierarchy of the dead within certain burial areas.

Even if it was an outside fossor who sold the loculus in the catacombs, funeral workers were often the agents entrusted with the task of interring a body in its proper spot next to a saint. An inscription usually denoted the specific position of the deceased. An early fourth-century Sicilian epitaph for an infant named Julia Florentina notes that "her body was buried in its tomb by the presbyter near the Martyrs' tombs on October 9." ${ }^{39}$ As this epitaph indicates, the demand for burials near saints was already in full swing by the late fourth century, and in some places, churches, through various types of personnel, were heavily involved. The inscription essentially notarizes a contract for these ad sanctos burials and holds the presbyter, a fossor, or other worker responsible. Another such inscription, this one from Rome, notes that two women, Valeria and Sabina, "During their lifetime, bought a place for two bodies from Apro and Victor in the new crypt behind the saints." ${ }^{\text {" } 0}$ Literally written in stone, these contracts were an attempt to assure the safety of a tomb, a growing apprehension in the catacombs at that time.

As this frenzy for burial spaces near saints raged, with tombs squeezed into overpopulated areas and burial places sometimes reopened in order to fit more burials, there emerged a new attitude of suspicion toward the sellers of the tombs and the workers within them. An inscription from Rome warns a fossor not to engage in such impious behavior as creating a double burial:

To the Spirits of the Dead.

Aurelius Niceta made this [tomb] for his well deserving daughter, Aurelia Aeliana.

See to it, gravedigger,

\footnotetext{
${ }^{37}$ Prudent. Perist. 2.541-544: "Vix fama nota est, abditis / quam plena sanctis Roma sit, / quam dives urbanum solum / sacris sepulcris floreat."

${ }^{38}$ ICUR n.s, 1.3127: "(sepulcrum intra 1)imina sanctorum, quod multi cupiunt et rari accipiunt."

${ }^{39}$ CIL 10.7112 = ILCV 1.1549: "Cuius corpus pro foribus martyrorum cum / loculo suo per presbiterum humatu(m) e(st) IIII Non(as) Oct(o)br(es)."

${ }^{40}$ ICUR $7.19432=I L C V$ 2153: "In $c r<y>$ pta no $<$ v $>$ a retro san/ctus emeru $<$ nt $>$ se vivas Baler/a et Sabina (e)meru<nt $>$ loc $/ \mathrm{u}(\mathrm{m})$ biso $<\mathrm{um}>$ ab Apronte et a / Biatore."
} 
that you do not dig here.

God has a vast eye.

Be aware that you too have children. ${ }^{41}$

As the protector of tombs, the gravedigger again became the default object of suspicion when there were tales of tomb resale. As they had in the earlier Roman Empire, law codes attempted to prevent gravediggers and other persons from reopening graves in order to bury new bodies, a scene glimpsed in Sidonius' letter to his nephew, which recounted how he had viewed his grandfather's tomb being dug up by gravediggers to make way for a new burial. ${ }^{42}$ As it had been in the Republic and earlier Roman Empire, tomb desecration was a continual problem; prestigious burials near saints were particularly vulnerable.

By the fifth century the desire for ad sanctos burials was so strong that Augustine felt compelled to address the problem in a treatise, De cura pro mortuis, written in response to a letter he had received asking what was to be gained by being buried next to a saint. He noted that nothing was to be gained from being buried next to a saint or martyr except the prayers given at feasts held near the saints on certain days of the year. ${ }^{43}$ The treatise appears to be an honest if ineffective attempt to defuse this status symbol. Even as the church began to involve itself in the selling of burial spaces in Rome and elsewhere, corruption continued to abound in the funeral trade-a situation that reflected poorly both on the church and on its mortuary workers.

Writing to Januarius, the bishop of Caralis, at the end of the sixth century, Pope Gregory I stated that a complaint had reached him from an elite Christian woman living within Januarius' bishopric in Sardinia stating that he was exacting exorbitant prices for performing burials. ${ }^{44}$ Januarius was accused not only of inflating burial costs but also of profiteering-a common accusation hurled at imperial Roman funeral directors-due to his profit from the death of others. According to Gregory, it was not in

${ }^{41}$ CIL 6.34635a = ILS 8195 = ILCV 3877: “D(is) M(anibus) / Aurelius Nice/ta Aureliae Aeli/ aneti filiae bene / merenti fecit / fossor vide ne / fodias deus ma/gnu(s) oc(u)lu(m) (h)abet vi/de et tu filios (h)abes." (Late fourth-early fifth century).

42 Sid.Apoll. Epist. 3.12.1: "Campus autem ipse dudum refertus tam bustualibus favillis quam cadaveribus nullam iam diu scrobem recipiebat . . . quae fuit causa, ut locum auderent tamquam vacantem corporum baiuli rastris funebribus impiare" ("The cemetery had for years been overcrowded with burned and unburned burials, and interment there had long ceased. . . . This explained how it was that some undertaker's men presumed to profane the spot with their gravedigging tools just as if it were unoccupied by human bodies": Ormonde M. Dalton, tr., The Letters of Sidonius [Oxford, 1915], 1.78).

${ }^{43}$ Aug. De cur. pro mort. 6.

${ }^{44}$ Greg.Mag. Epist. 9.3. 
either the Jewish or Christian spirit to exact a profit from burial; he further admonished the bishop to stop extorting, not only from grieving parishioners but also from strangers. ${ }^{45}$ These cases all bear striking resemblance to the problem of extortionate burial prices that persisted in Constantinople even in the sixth century. ${ }^{46}$

The lucrative funeral market and the competition for prime burial spots did not go unrecognized by some who wished to reform the system. The epitaph of the archdeacon Sabinus at the entrance to the Basilica of St. Lawrence in Rome indicates not only the high demand for ad sanctos burials in Late Antiquity but also attempts by some clergy to reverse the practice of paying gravediggers to place a body near a saint-even if the space was owned by another: "It not advantageous that he digs a tomb close by the tombs of the pious. It is a life of virtue that brings him near the merits of the saints. Let us hold on to those not in body but in spirit, which will itself be the salvation of our body." ${ }^{27}$ Augustine's treatise on the care of the dead, contemporaneous with this epitaph, also warns others not to value positions near a saint so highly. It was only one of many such theological treatises written to try and diffuse the fervor over the cult of the saints. For other bishops, the growth of the cult of the saints was an opportunity. A great patron of the fossores in Rome was also the man who initially and heavily promoted the growth of the cult of the saints in the city: bishop Damasus. ${ }^{48}$ The existence of this patronage relationship alone does not prove the clerical status of fossores, but it does support an argument for a strong affiliation between the bishop and mortuary associations active in the Roman catacombs.

The cult of the saints is a widely attested phenomenon in Late Antiquity; but little attention has been paid to the lower-level personnel that facilitated and exploited the cult for their own financial gain and who aided many

${ }^{45}$ Gregory cites the case in Genesis (23) of Ephron, who refused to charge Abraham for a sepulcher lest he be accused of making a profit off the burial.

${ }^{46}$ Nov.Just. 59 (537 CE): "Plurimi plerumque adierunt nos dicentes non similiter causam procedere neque sine mercede fieri defunctorum exequias, sed exigi amare, et inveniri plurima foris nomina et corpora, quae etiam invitos exigunt lugentes et cogent dare non habentes" ("Now many, from various places, have come before us, complaining that no equality is being observed in this matter; that the burial of the dead is not being made free of charge, but that the expenses are being harshly collected and that there are many other persons and associations collecting [the costs] from people that the deceased left behind and making those who don't have anything pay").

${ }^{47}$ ICUR n.s. 7.18017 = ILCV 1194: "Nil iuvat immo gravat tumulis haerere piorum / sanctorum meritis optima vita prope est / corpore non opus est anima tendamus ad illos / quae bene salva potest corporis esse salus."

${ }^{48}$ Damasus placed carmina on saints' tombs, decorated others, and promoted the tombs of Paul and Peter; see Alan Thacker, "Rome of the Martyrs: Saints, Cults, and Relics, Fourth to Seventh Centuries,” in É.Ó. Carragáin, C.L. Neuman de Vegvar, eds., Roma Felix: Formation and Reflections of Medieval Rome (Burlington, 2007), 34-35. 
churches in their extension into the funeral trade. The commercial endeavors of the church were not limited to the funerary market, and it was always difficult to reconcile the ecclesiastical and commercial spheres. Unlike their pagan predecessors, the funerary personnel within the increasingly Christian world of the later fourth century were endowed with a new status yet fettered by greater moral expectations. It was indeed difficult to espouse the Christian ideals of philanthropy and universal burial while also tapping into the enticing commercial opportunities provided by a funerary market fueled by the elite demand for ad sanctos burials. Martyrologies, hagiography, and patristic writing had cleansed the gravedigger of his former sins; yet the corrupting power of money helped to tarnish his reputation once again. The return of the gravedigger to the earlier status of profiteer marks a final trend among late antique funeral workers: the abuse of the privileges given them by the state.

\section{Funeral Workers and Corruption in Late Antiquity}

An imperial constitution from $400 \mathrm{CE}$ notes the influx of persons into clerical service in order to provide funerals:

Since we have learned that many persons either before their military service or after it has begun but not been completed, are hiding under the pretext of religious devotion, while they are protecting themselves by the title of clerics and are occupied in unholy obsequies for the dead, attracted not so much by the service of their religion as by their love of leisure and laziness, We permit no person at all to be exempted by such a pretext. ${ }^{49}$

Honorius cites the attractive lifestyle-one filled with otium-as a primary reason for the great increase in clerical mortuary workers; more likely, as has been seen, it was the tax break and relief from civic burdens that made the job more attractive. By the fifth century, in the wake of the demand for ad sanctos burials, the surge in mortuary employment was perhaps also due to the lure to the lucrative market that had been created surrounding the saints within many churches. As churches grew to control a continually larger portion of burial real estate, greater financial gains were seen to be made from elite who wished, at any price, to place their loved ones next to a saint. Although "at the lowest level of ecclesiastical hierarchy opportunities for large-scale corruption were lacking," if the exploitation of mourning families throughout the Roman

${ }^{49}$ CTh 7.20.12.2 (30 January 400): "Et quoniam plurimos vel ante militiam vel post inchoatam vel peractam latere obiectu piae religionis agnovimus, dum se quidam vocabulo clericorum et infaustis defunctorum obsequiis occupatos non tam observatione cultus quam otii et socordiae amore defendunt, nulli omnino tali excusari obiectione permittimus," Clyde Pharr, tr., The Theodosian Code and Novels and the Sirmondian Constitutions (Princeton, 1952), 182. 
Empire is compounded and reckoned cumulatively, the corruption may have had a larger impact than previously considered. ${ }^{50}$

In a novel of $536 \mathrm{CE}$ the emperor Justinian instructed Longinus, the city prefect of Constantinople, to exempt only the 1,100 workshops within the city of Constantinople-the 800 under contract to provide a decanus, lecticarius, or burial supplies, and 300 directed to pay into Anastasius' fund to pay these burial attendants-from the burdens imposed on city merchants. ${ }^{51}$ Just a year and a half later, in November of 537, Justinian issued a second ruling concerning the funeral workers in Constantinople-one that again confirmed the limit on workshops that could receive the exemption but supplied greater detail concerning the regulation and funding of the city's Christian burials that Constantine had first established. ${ }^{52}$ This second novel was sent to the praetorian prefect of the east and sought to set the prices paid to the workshops and to create safeguards against corruption. ${ }^{53}$ Justinian reestablished Anastasius' fund, originally intended to defray the cost of burials, employ funeral workers, and pay the salaries of other requisite Christian funeral attendants: acolytes, ascetriae (female hermits), and cannonicae. ${ }^{54}$ Justinian lamented the many problems and corruptions of the burial system in Constantinople, yet there is something to be learned from the system besides that a welfare state was not yet fully realized.

Geographically, the corruption involving gravediggers and hospital workers was apparent in the west-the edict of Honorius was issued in Milan but does not address a specific region-but appears to have been more rampant in the east, where many claimed the enticing exemptions granted to decani, lecticarii, and copiatae in cities such as Constantinople and Antioch. Imperial laws from the fourth to the sixth century can give us hints as to the problems involving increasingly larger collegia of gravediggers and funerary workers

${ }^{50}$ Antigone Samellas, Death in the Eastern Mediterranean (50-600 A.D.): The Christianization of the East: An Interpretation (Tubingen, 2002), 275.

${ }^{51}$ Nov.Just. 43. The urban prefect of Constantinople appears to have been in charge of the systemata (associations) of craftsmen connected to the many workshops, called officinae or ergasteria, within the city. A ruling of 391 established that the city prefect was responsible for knowing all of the merchant associations in Constantinople (CJ 1.28.4 = CTh 1.10.4). Taxes: The tax burden was indeed heavy from Diocletian onward. Exemptions awarded to clerici of the church and certain other government officials were especially valuable. The original exemption here likely refers to the collatio lustralis, a tax imposed on merchants until Anastasius abolished it in $498 \mathrm{CE}$. Afterward there were still merchant taxes, but none as oppressive as the collatio lustralis.

${ }_{52}$ Nov.Just. 59.

${ }^{53}$ The praetorian prefect (eparch) of the east, normally stationed in Constantinople, directed the collection of the annona. He was the head of the police force-the taxiotai-and also controlled trade and industry; James A.S. Evans, The Age of Justinian: The Circumstances of Imperial Power (London/New York, 2000), 43-44.

${ }^{54}$ Nov.Just. 59.2. 
within the Roman Empire; this, combined with the textual and epigraphic evidence, outlines the importance of these collegia not only to urban burial schemes and to the presiding bishop but also to the worker himself. Constantine's associations of funeral workers had the strength of the government and the church behind them in Constantinople and had powerful allies. The benefits they received were part of a larger trend throughout the Roman Empire, wherein clergy received special privileges and favored status. ${ }^{55}$

\section{Conclusion}

As described above, the elevation of funeral workers within some early churches was magnified following the emperor Constantine's conversion to Christianity and his institution of associations of funeral workers in Constantinople. The establishment of funerary ordines subsidized by the state but directed by bishops had a larger impact than has previously been recognized, as a paradigm for burial schemes in other cities and in the creation of a new path for status, in the redirection of patronage networks from the state to the church, and in increasing the involvement of churches in the funeral trade. Although the funerary profession in the Roman Empire still included many private entrepreneurs, it now incorporated large groups of clerical or paraclerical workers in some late antique cities, some of whom not only received enticing tax and military service exemptions but also became clients to the local bishop. These changes in status and patronage, together with the often dire economic and military conditions in the Mediterranean region, made the job of funerary worker attractive to those looking to evade heavy financial burdens or to avoid dangerous work as a soldier and allowed some to gain a powerful advocate as their new patronus. To some bishops, such as Damasus and Cyril, the episcopal role in the patronage and oversight of these corps provided an opportunity to utilize them as personal gangs. Associations such as the parabolani in Alexandria and the lecticarii in Antioch were beholden to the bishop for patronage; and in the competitive political and religious feuds between bishops in Late Antiquity, corps of funeral workers are sometimes identified as instruments of violence. These funeral corporations provide further evidence that the establishment of bishops as patrons over numerous civic associations that served late antique cities amplified the social influence of bishops and created an opportunity for personal abuse and corruption.

\footnotetext{
55 As Michele Renee Salzman, The Making of a Christian Aristocracy: Social and Religious Change in the Western Roman Empire (Cambridge, 2002), 195.
} 
The law codes suggest, although by no means prove, that the burial scheme established by Constantine was an ideal rather than a reality. By the mid-sixth century, when Justinian noted the scheme in his novels, his tone was one of exasperation and firmness, an emperor reacting to the city's chronic problems with the mortuary industry: impostors impersonating funeral workers, workshops and other institutions unjustly citing the tax loophole, patrons using the associations for a private militia, and funeral workers overcharging or misrepresenting the cost of their services. Constantine appears to have been the first to offer a broad tax exemption in return for funeral services and workers, but this subsidy-originally conceived as a means to entice merchants to provide the labor and accoutrements essential for the proper burial of thousands of the Christian poor-clearly bred new problems in terms of tax evasion and bishops' using funeral workers as personal clientes. This scheme also aided the domination of the funeral trade by the church. During the reign of Justinian, the Christianized funeral trade does not appear to have been very dissimilar to the funerary trade of the republican period, except for one key difference: the status and patronage bonds of the funerary workers within the late antique mortuary associations. With the increasing demand for ad sanctos burials among the wealthy in early medieval society, bishops and their funeral workers had a new selling point with which to mark up the cost of burial for the elite. These workers in the army of Christ began to become notorious once again and to resemble their profiteering predecessors-this time with status and protection provided by a new patron, the church. 